\title{
Peran Teacher Autonomy Support terhadap Engagement Siswa melalui Pemenuhan Kebutuhan Psikologis Dasar
}

\section{Meilani Rohinsa, Surya Cahyadi, Achmad Djunaidi, Tb. Zulrizka Iskandar}

\author{
Fakultas Psikologi Universitas Padjadjaran \\ email: rohinsa.meilani@gmail.com
}

\begin{abstract}
Abstrak
Artikel INFO

Diterima:28 Agustus 2019

Direvisi :02 sept 2019

Disetujui: 25 Okt 2019

DOI:

http://dx.doi.org/10.24014/ jp.v14i2.7423

Tujuan pendidikan formal akan tercapai apabila siswa terlibat atau engage dalam aktivitas pembelajaran Dengan siswa engage terhadap kegiatan belajarnya, maka siswa akan semakin terdorong untuk belajar dan semakin ingin mengasah keterampilan yang dibutuhkan untuk sukses di sekolah. Diperlukan peran serta guru untuk membentuk engagement siswa terhadap aktivitas belajarnya. Penelitian ini bertujuan untuk menginvestigasi apakah pemenuhan kebutuhan psikologis dasar memediasi pengaruh teacher autonomy support terhadap engagement. Responden dalam penelitian ini adalah 213 siswa SMA, yang terdiri dari Wanita $=126(59.2 \%)$ dan Laki-laki $=87$ (40.8\%). Alat ukur yang digunakan adalah kuesioner Autonomy support, Feeling I Have dan Engagement. Data dianalisis dengan uji regresi berganda. Hasil penelitian ini menunjukkan pemenuhan kebutuhan psikologis dasar memediasi pengaruh teacher autonomy support terhadap engagement. Implikasi dari temuan ini bahwa guru harus menyadari bahwa setiap siswa memiliki kebutuhan psikologis dasar yang dapat dipenuhi oleh perlakuan guru berupa autonomy support dan hal ini akan membentuk engagement siswa terhadapa aktivitas belajar di kelas.
\end{abstract}

Kata-kata kunci: Teacher autonomy support, Pemenuhan kebutuhan psikologis dasar, Engagement

\section{The Influence of Teacher Autonomy Support Toward to Engagement Through Basic Need Satisfaction in Senior High School Student}

\begin{abstract}
The goal of formal education will be achieved if students engage or engage in learning activities. With students engaging in learning activities, students will be increasingly motivated to learn and increasingly want to hone the skills needed to succeed in school. Teacher participation is required to form student engagement in learning activities. The current research aims to investigate whether students' basic need satisfaction can mediate the effect of teacher' autonomy support in predicting senior high school students' engagement. The participant of the research are 213 senior high school students (Female $=126(59.2 \%)$ and Male $=87$ $(40.8 \%)$. Instrument in the current research included Teacher Autonomy Support Questionnaire, Feeling I Have and Engagement Questionnaire. Data analysis was conducted using multiple regression tests. Bases on research finding, Basic Need Satisfaction mediates the effect of teacher autonomy support in predicting senior high school students' engagement. Findings of the study were discussed under the light of relevant literature, and some suggestions were made for future research. The implication of this finding is that teachers need to be aware that every student has basic psychological need that can be met by teacher structure. This support will shape students' engagement with learning activities in the classroom.
\end{abstract}

Keyword: Teacher autonomy support, Basic need satisfaction, Engagement

\section{Pendahuluan}

Keberhasilan program belajar yang dicanangkan di suatu sekolah sangat tergantung berbagai hal, salah satunya adalah keterlibatan siswa terhadap berbagai aktivitas di sekolah, atau yang disebut dengan 'student engagement', 'academic engagment','school engagement' atau 'engagement'. Dimana untuk selanjutnya dalam penelitian ini akan digunakan istilah engagement. Terutama tuntutan pembelajaran yang dihadapi siswa saat ini, yang menuntut siswa untuk lebih aktif mengeksplorasi kemampuan dirinya dalam proses belajar (https://www.kemdikbud. go.id). Saat ini guru tidak lagi menyampaikan materi secara langsung kepada siswa, melainkan guru lebih banyak memberikan stimulasi berupa gambar, persoalan ataupun pertanyaan yang berkaitan dengan suatu materi. Siswalah yang nantinya akan mencari jawaban atas persoalan/ pertanyaan yang 
diajukan oleh guru tersebut. siswa juga diharapkan dapat melakukan suatu aktivitas yang nantinya diharapkan melalui aktivitas tersebut siswa dapat memahami materi secara mandiri. Dengan kata lain untuk menghadapi tuntutan pembelajaran saat ini, siswa diharapkan dapat lebih terlibat atau engage dengan aktivitas belajarnya di kelas.

Engagement dianggap sebagai suatu konstruk yang relevan bagi semua siswa (Appleton, Christenson \& Furlong, 2008). Engagement merupakan hal yang penting bagi siswa karena bukan saja diperlukan agar siswa dapat menguasai keterampilan ataupun kemampuan yang diajarkan di sekolah, engagement juga diperlukan agar siswa dapat beradaptasi dengan tuntutan pendidikannya (Connell \& Wellborn, 1991). Dengan siswa engage terhadap kegiatan belajarnya, maka siswa akan semakin terdorong untuk belajar dan semakin ingin mengasah keterampilan yang dibutuhkan untuk sukses di sekolah (Lawson \& Lawson, 2013). Dari berbagai penelitian yang telah ada juga dapat disimpulkan bahwa engagement adalah faktor yang penting bagi learning dan academic achievement (Finn \& Zimmer, 2012).

Engagement didefinisikan sebagai keterlibatan perilaku yang berkelanjutan dalam aktivitas belajar yang disertai dengan nada emosi yang positif terhadap aktivitas belajar di kelas (Skinner \& Belmont, 1993). Dalam penelitiannya yang terbaru (Skinner \& Pitzer, 2012a) melihat engagement sebagai konstruk yang terintegrasi, artinya engagement digambarkan sebagai komponen perilaku yang terintegrasi dengan komponen emosi.

Dalam konsep Skinner \& Pitzer (2012) engagement dapat dikaji dalam 3 level yang berbeda. Salah satu level yang paling penting dalam mempelajari engagement adalah keterlibatan siswa terhadap kegiatan belajar di kelas atau engagement with learning activities. Penelitian ini akan memfokuskan pada engagement with learning activity, hal ini dikarenakan pada saat di sekolah siswa menghabiskan sebagian besar waktunya dengan mengikuti aktivitas di kelas. Dan dengan siswa berpartisipasi di kelas, maka siswa akan memperoleh sikap, keterampilan dan pengetahuan yang dicanangkan dalam program belajar di sekolah. Dapat dikatakan kegiatan belajar dikelas merupakan komponen yang paling penting bagi tercapainya suatu kurikulum dan tujuan pembelajaran.
Engagement bukanlah merupakan suatu trait yang sudah pasti. Banyak peneliti yang berargumentasi bahwa engegment adalah kondisi yang lunak yang dapat di bentuk oleh lingkungan (Fredricks, Blumenfeld, \& Paris, 2004b). Dalam berbagai literatur terdapat 3 pihak dari konteks sosial yang dianggap berpengaruh terhadap engagement siswa, yaitu keluarga (orangtua), guru dan teman sebaya. Interaksi interpersonal ini dianggap dapat mengembangkan engagement dan achievement siswa di sekolah (Skinner \& Pitzer, 2012a). Siswa menghabiskan sebagian besar waktunya di sekolah, terutama di kelas. Oleh karena itu interaksi siswa dengan guru di kelas dapat dikatakan sebagai sesuatu yang paling dekat dan secara potensial dapat memengaruhi motivasi maupun engagement (Newmann, King, \& Youngs, 2005).

Terdapat suatu bentuk dukungan guru yang dapat memengaruhi engagement siswa (Deci \& Ryan, 2017; Connell \& Wellborn, 1991) salah satunya adalah autonomy support yang merupakan dimensi utama dari bentuk dukungan lingkungan dalam self determinan theory. Teacher Autonomy support adalah proses aktif yang melibatkan penerimaan guru atas sudut pandang siswa, seperti guru menunjukkan kesediaan untuk mendengarkan pendapat siswa, memberikan kesempatan pada siswa untuk memilih dan mengambil suatu keputusan yang berkaitan dengan aktivitas di kelas, serta guru memberikan alasan yang rasional yang menyangkut kepentingan siswa pada saat menyampaikan materi pelajaran, saat meminta siswa mengerjakan tugas ataupun menetapkan suatu aturan. Peran guru dalam memberikan autonomy support bagi siswanya dapat memenuhi kebutuhan psikologis dasar dari siswa. Terdapat tiga kebutuhan psikologis yang mendasar yang terdapat dalam diri setiap manusia, kebutuhan ini adalah kebutuhan akan terikatan (need for relatedness), kebutuhan akan kompetensi (need for competence) dan kebutuhan akan otonomi (need for autonomy). Dapat dikatakan bagi semua orang menjadi penting untuk merasa disukai ataupun diterima oleh oleh orang lain, merasa dirinya mampu dan merasa memiliki kebebasan untuk mengekspresikan dirinya sendiri.

Autonomy support dari bukan saja dapat memenuhi kebutuhan autonomy, namun juga dapat memenuhi kebutuhan competence dan relatedness dalam diri siswa. Gronlnick, Ryan \& Deci (1991) menemukan 
bahwa seseorang yang mempersepsi lingkungannya lebih autonomy support merasa lebih kompeten dibandingkan dengan siswa yang mempersepsi lingkungannya lebih mengendalikan dirinya. Guru yang menunjukkan autonomy support akan membuat siswanya untuk mengembangkan penghayatan bahwa dirinya sebagai penyebab tindakan mereka sendiri, atau perasaan bahwa dirinya memiliki otonomi (sense autonomy). Perlakuan autonomy support dari guru juga sekaligus dapat membuat siswa merasa dirinya kompeten (sense competence). Pada saat lingkungan memberikan kesempatan pada anak untuk mengambil suatu keputusannya sendiri, melakukan aktivitas yang dipilihnya (autonomy support), maka hal ini akan mempengaruhi bagaimana cara akan memandang kemampuan dirinya. Dengan adanya kebebasan dan kepercayaan yang diberikan oleh lingkungan untuk mengatur tindakannya, maka akan membuat anak merasa bahwa dirinya memiliki kemampuan untuk mencapai sesuatu (sense competence). Selain itu perlakuan guru yang menghargai pendapat anak yang juga menjadi bagian dari autonomy support ini dapat memfasilitasi terpenuhinya need for relatedness pada siswa, dimana merasa dihargai, diterima oleh lingkungannya (sense relatedness).

Pada saat guru memberikan autonomy support kepada siswa, maka terjadi suatu proses dalam diri siswa, siswa akan menilai apakah kebutuhan psikologis dasar dalam dirinya terpenuhi atau tidak dari perlakuan lingkungan tersebut. Proses penilaian inilah yang disebut dengan self system process
(Connell \& Wellborn, 1991). Apabila siswa menghayati bahwa kebutuhan psikologis dasarnya terpenuhi maka akan menimbulkan persepsi dalam diri siswa bahwa dirinya memiliki sense autonomy, sense competence, dan sense relatedness yang berkaitan dengan aktivitas belajarnya.

Deci dan Ryan (2000) menjelaskan bahwa terpenuhinya ketiga kebutuhan psikologis dasar akan memunculkan energi yang terarah pada tujuan, bahkan mengarah pada munculnya motivasi intrinisik dalam melakukan aktivitas. Motivasi intrisik ini akan muncul dalam bentuk perilaku siswa yaitu engagement siswa terhadap lingkungan, yang dalam hal ini adalah aktivitas di kelas (Wellborn and Connell, 1991). Dengan memiliki motivasi instrisik untuk belajar, maka siswa akan memiliki energi psikis yang ditunjukkan melalui usahanya untuk menguasai materi pelajaran. Mereka juga lebih mengembangkan regulasi diri dalam konteks belajar, seperti mengendalikan perilakunya untuk fokus pada aktivitas belajar di kelas (engagement). Meskipun konsep ini sucah cukup banyak dibuktikan di negara barat, namun sepengetahuan peneliti, masih terbatas penelitian empiris yang membuktikan mengenai hal ini, terutama di Indonesia yang memiliki budaya yang berbeda dengan budaya barat. Oleh karena itu penelitian ini bertujuan menjelaskan, apakah pemenuhan kebutuhan psikologis dasar memediasi pengaruh teacher autonomy support terhadap engagement, pada siswa SMA di Bandung. Tujuan penelitian ini digambarkan dalam skema penelitian sebagai berikut

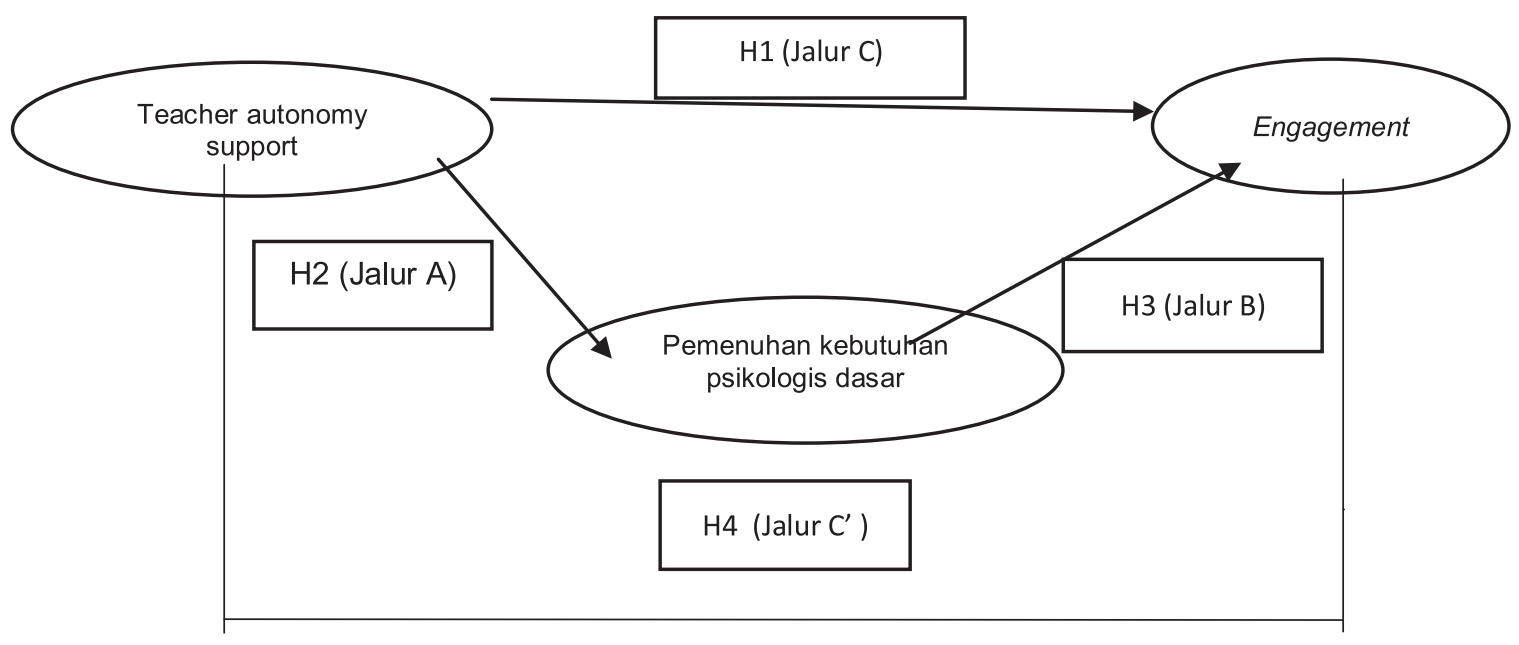

Gambar 1 Skema penelitian 
Adapun Hipotesa yang akan diuji dalam penelitian ini adalah :

Hipotesis Mayor : Pemenuhan kebutuhan psikologis dasar memediasi pengaruh teacher autonomy support terhadap engagement.

Hipotesis Minor :

1. Teacher autonomy support memiliki pengaruh yang positif signifikan dengan engagement.

2. Teacher autonomy support memiliki pengaruh yang positif signifikan dengan pemenuhan kebutuhan psikologis dasar.

3. Pemenuhan kebutuhan psikologis dasar memiliki pengaruh yang positif signifikan terhadap engagement.

\section{Metode}

Desain penelitian dan Partisipan

Jenis penelitian ini adalah desain korelasional. Menurut Heppner, Wampold \& Kivlighan (2013), desain korelasional digunakan untuk mempelajari hubungan antara dua variabel atau lebih. Penelitian ini akan menguji hubungan antara variabel teacher autonomy support (yang merupakan variabel eksogen), pemenuhan kebutuhan psikologis dasar (varibael intervening) dan engagement (variabel endogen). Populasi penelitian ini adalah siswa yang suatu SMA di Bandung, pada tahun ajaran 2018/2019. Dengan mengunakan teknik quota sampling, maka seluruhnya terdapat 213 responden yang digunakan dalam penelitian ini. Usia rata rata dari masing-masing responden 15.41 tahun $(S D=0,51$, dengan rentang usia 14-18 tahun). Wanita $=126$ (59.2\%) dan Lakilaki $=87(40.8 \%)$.

\section{Pengukuran}

Teacher autonomy support .Diukur menggunakan kuesioner Autonomy support dari Skinner dan Belmont (1993). Alat ukur ini terdiri dari 21 item yang mengukur persepsi siswa menganai apakah guru mereka memberikan mereka pilihan, menghargai ide dan pendapat mereka, dan menjelaskan relevansi aktivitas belajar di kelas bagi diri mereka (contoh: "guru saya memberikan saya banyak pilihan mengenai bagaimana melakukan tugas-tugas saya"). $B ß$ Tersedia empat pilihan jawaban yaitu Tidak Sesuai (TS), Kurang Sesuai (KS), Cukup Sesuai
(CS), dan Sangat Sesuai (SS). Kuesioner asli yang berbahasa Inggirs telah di translate ke dalam bahasa Indonesia oleh penulis kedua (Meilani) dan telah di cek oleh ahli bahasa Inggris. Konsistensi internal, diukur menggunakan Alpha Cronbach, yaitu 0.67 yang dapat di kategorikan sebagai acceptable (DeVellis, 1991).

Pemenuhan Kebutuhan Psikologis Dasar. Diukur menggunakan Alat ukur Feeling I Have dari Deci \& Ryan (2000). Alat ukur ini terdiri dari 21 item yang mengukur persepsi siswa mengenai pemenuhan kebutuhan psikologis dasar (contoh: "pada umumnya saya merasa bebas menyatakan ide dan pendapat saya."). Tersedia empat pilihan jawaban yaitu Tidak Sesuai (TS), Kurang Sesuai (KS), Cukup Sesuai (CS), dan Sangat Sesuai (SS). Kuesioner asli yang berbahasa Inggirs telah di translate ke dalam bahasa Indonesia oleh penulis kedua (Meilani) dan telah di cek oleh ahli bahasa Inggris. Konsistensi internal, diukur menggunakan Alpha Cronbach, yaitu 0.77 yang dapat di kategorikan sebagai respectable (DeVellis, 1991).

Engagement. Diukur dengan menggunakan kuesioner Engagement dari Skinner dkk (2009). Alat ukur ini terdiri dari 25 item yang mengukur engagement siswa terhadap aktivitas belajar di kelas (contoh: "saya bekerja keras pada saat saya memulai sesuatu yang baru di kelas"). Tersedia empat pilihan jawaban yaitu Tidak Sesuai (TS), Kurang Sesuai (KS), Cukup Sesuai (CS), dan Sangat Sesuai (SS). Kuesioner asli yang berbahasa inggirs telah di translate ke dalam bahasa Indonesia oleh penulis kedua (Meilani) dan telah di cek oleh ahli bahasa Inggris. Konsistensi internal, diukur menggunakan Alpha Cronbach, yaitu 0.78 yang dapat dikategorikan respectable (DeVellis, 1991).

\section{Hasil}

Hasil Uji Regresi antara Teacherautonomy support dan Engagement menunjukkan hasil $ß=0.19$, dengan sig $=0,013(p<0.05)$. Hal ini menunjukkan terdapat hubungan yang positif namun termasuk dalam kriteria yang sangat lemah (menurut kriteria Sarwono, 2006) antara teacher autonomy support dan engagement. Teacher autonomy support diasumsikan dapat memprediksi munculnya engagement.

Hasil Uji Regresi antara teacher autonomy support dan Pemenuhan Kebutuhan Psikologis Dasar menunjukkan $B=$ 0,26 , dengan sig. $0.00 \quad(p<0.05)$. hal ini 
menunjukkan terdapat hubungan yang positif yang cukup kuat (menurut kriteria Sarwono, 2006) antara Teacher autonomy support dan pemenuhan kebutuhan psikologis dasar. Teacher autonomy support diasumsikan dapat memprediksi munculnya pemenuhan psikologis dasar.

Hasil Uji Regresi antara Pemenuhan Kebutuhan Psikologis Dasar dan Engagement hal ini menunjukkan $B=0.24$, dengan sig $0.004(p<0.05)$. Hal ini menunjukkan terdapat hubungan yang positif yang sangat lemah (menurut kriteria Sarwono, 2006) antara pemenuhan kebutuhan psikologis dasar dan engagement. pemenuhan kebutuhan psikologis dasar diasumsikan dapat memprediksi munculnya engagement.

Hasil Uji Regresi berganda antara Teacher autonomy support, Pemenuhan Kebutuhan Psikologis Dasar dan Engagement menunjukkan Direct effect (jalur c') koefisen regresinya turun dari 0.26 menjadi 0.19 . Hal ini menunjukkan bahwa hubungan Teacher autonomy support dan Engagement dapat dimediasi oleh Pemenuhan kebutuhan psikologis dasar, dan hubungan kedua variabel itu tetap positif. Hal ini dilihat dari nilai standardized coefficient dari kedua variabel tersebut $\beta=0.14$. Hubungan langsung kedua variabel tersebut menunjukkan $p$ yang lebih besar dari 0.05 yakni sebesar 0.074 , sehingga menurut Baron dan Kenny (1986) terjadi full mediation dalam penelitian ini. Hal ini juga terbukti ketika menggunakan kalkulator Sobel Test diketahui bahwa nilai $z=2.28>$ 1.96 (nilai z mutlak) sehingga terbukti secara signifikan terdapat pengaruh tidak langsung dari Teacher Autonomy Support terhadap Engagement, dan pemenuhan kebutuhan psikologis dasar terbukti mampu memediasi pengaruh Teacher Autonomy Support terhadap Engagement.

\section{Pembahasan}

Berdasarkan dari analisis data, seperti yang dapat dilihat pada tabel 1 , terbukti bahwa Teacher autonomy support memiliki pengaruh yang signifikan terhadap engagement (jalur c). Teacher autonomy support juga memililiki pengaruh yang signifikan terhadap pemenuhan kebutuhan psikologis dasar (jalur a). Dari analisis data juga di peroleh bahwa pemenuhan kebutuhan psikologis dasar memiliki pengaruh yang signifikan terhadap engagement (jalur b).

Berdasarkan uji regresi berganda ditemukan bahwa direct effect (jalur c') antara Teacher autonomy support, Pemenuhan Kebutuhan Psikologis Dasar dan Engagement mengalami penurunan koefisien regresinya turun. Hal ini menunjukkan bahwa teacher autonomy support dan engagement dapat dimedisiasi oleh pemenuhan kebutuhan psikologis dasar dengan full mediation. Data ini menunjukkan bahwa dalam penelitian ini teacher autonomy support terbukti tidak dapat memengaruhi engagement tanpa melalui terpenuhinya kebutuhan psikologis dasar para siswa.

Temuan lain dalam penelitian ini adalah meskipun terdapat korelasi positif antara variabel teacher autonomy support dan engagement, namun korelasinya sangat lemah. Hal ini berarti, korelasi antara teacher autonomy support dan engagement dapat dimediasi secara full mediation dengan variabel pemenuhan kebutuhan psikologis dasar. Dengan demikian dapat disimpulkan semakin positif penghayatan siswa terhadap teacher autonomy support maka siswa akan mempersepsi kebutuhan psikologis dasarnya terpenuhi yang ditandai dengan siswa memiliki perasaan bahwa dirinya disukai ataupun diterima oleh oleh orang lain, merasa dirinya mampu dan merasa memiliki kebebasan untuk mengekspresikan dirinya sendiri. Adanya perasaan ini dalam diri siswa akan membuat siswa menunjukkan keterlibatan terhadap aktivitas belajarnya. Sebaliknya semakin negatif penghayatan siswa terhadap teacher autonomy support maka siswa akan mempersepsi kebutuhan psikologis dasarnya tidak terpenuhi, yang ditunjukkan dengan perasaan siswa bahwa dirinya tidak disukai ataupun diterima oleh oleh orang lain, merasa dirinya tidak mampu dan merasa tidak memiliki kebebasan untuk mengekspresikan dirinya sendiri, sehingga pada akhirnya siswa akan kurang bahkan tidak menunjukkan keterlibatan terhadap aktivitas belajarnya.

Menurut Connell dan Wellborn, 1991 pada saat siswa mendapatkan autonomy support dari lingkungan, dalam hal ini adalah dari guru maka akan terjadi suatu proses dalam diri siswa untuk menilai apakah kebutuhan psikologis dasar dalam dirinya terpenuhi atau tidak dari perlakuan guru tersebut. Proses penilaian inilah yang disebut dengan self system process (Connell \& Wellborn, 1991; Skinner \& Belmont, 1993, Skinner \& Pitzer, 2012). Apabila berdasarkan self system process siswa menghayati bahwa 
kebutuhan psikologis dasarnya terpenuhi maka akan menimbulkan persepsi dalam diri siswa bahwa dirinya autonomy, competence, relatedness. Persepsi siswa mengenai dirinya ini akan menentukan bagaimana siswa melakukan aksi di kelas, dimana engagement dan disaffection merupakan bentuk dari aksi yang dapat dilakukan siswa di kelas.

Berdasarkan uji hipotesis minor yang pertama, diperoleh hasil yang menunjukan adanya korelasi positif dan signifikan antara kedua variabel tersebut. Dapat diasumsikan bahwa semakin positif pengahayatan siswa terhadap teacher autonomy support maka akan semakin engage siswa terhadap aktivitas belajarnya. Hasil di atas membuktikan bahwa hipotesis pertama mengenai hubungan positif signifikan antara teacher autonomy support dan engagement diterima walaupun korelasi positif yang terbangun dari kedua variabel tersebut termasuk dalam kruteria sangat lemah menurut Sarwono (2006).

Autonomy support yang diterima siswa dari guru akan memberikan dampak bagi siswa. Melalui penjelasan yang disampaikan guru mengenai alasan mengapa suatu aturan perlu dilakukan atau pengapa suatu materi perlu dipelajari, akan membantu siswa untuk memahami manfaat dari hal tersebut bagi dirinya, sehingga siswa melakukan sesuatu bukan karena sekedar mengikuti arahan dari guru. Selain itu, dengan siswa mengalami bahwa guru bersedia mendengarkan pendapatnya dan memberikan kesempatan untuk memilih dan membuat suatu keputusan sendiri, maka hal ini akan membuat siswa memiliki perasaan bahwa dirinya merupakan agen yang aktif, yang artinya segala tindakannya dilakukan atas keinginannya sendiri (Connell \& Wellborn, 1991). Perasaan bahwa dirinya adalah agen yang aktif ini membuat siswa lebih bertanggung jawab terhadap tindaknya. Terlebih siswa juga paham mengenai pentingnya aktifitas belajar bagi dirinya, maka hal ini akan mendorong siswa untuk perpartisipasi terhadap kegiatan belajar, memiliki inistif dalam mengerjakan tugas-tugasnya di kelas (Reeve \& Jang, 2006).

Selanjutnya berdasarkan hasil uji hipotesis minor kedua, didapati hasil yang menunjukkan adanya korelasi positif yang termasuk korelasi cukup kuat dan signifikan antara kedua variabel tersebut. Hasil di atas membuktikan bahwa hipotesis kedua mengenai hubungan positif signifikan anatra teacher autonomy support dan pemenuhan kebutuhan psikologis dasar diterima.

Teori Self Determination Theory, atau yang selanjutnya disingkat dengan SDT menyatakan bahwa sesuatu dalam diri yang harus dipuaskan untuk pertumbuhan kognitif dan perkembangan ini sebagai kebutuhan psikologis dasar (Ryan dan Deci, 2000). Menurut sudut pandang SDT, kebutuhan psikologis dasar merupakan hal yang universal dan lintas tahap perkembangan. setiap orang memiliki kebutuhan dasar. Dan pada saat kebutuhan dasar ini dipenuhi oleh konteks sosial. Konteks sosial berperan untuk memenuhi atau tidak memenuhi ketiga kebutuhan psikologis dasar tersebut. Bentuk peranan konteks sosial dalam pemenuhan kebutuhan psikologis dasar dalam diri manusia, yang salah satunya dapat berupa perlakuan autonomy support. Pada saat seseorang mendapatkan perlakuan dari konteks sosial, akan terjadi suatu proses di dalam dirinya untuk menilai apakah kebutuhan psikologis dasar dalam dirinya terpenuhi atau tidak oleh perlakuan dari lingkungan tersebut. Proses penilaian inilah yang di sebut dengan self system prossess (Connell \& Wellborn, 1991). Apabila berdasarkan self system process seseorang menghayati bahwa kebutuhan psikologis dasarnya terpenuhi, maka akan menimbulkan persepsi bahwa dirinya competence, autonomy, relatedness. Ketiga persepsi mengenai diri ini yang selanjutnya akan disebut dengan sense competence, sense autonomy,dan sense relatedness (Connell and Wellborn, 1991).

Hasil uji hipotesis minor yang ketiga diketahui bahwa hubungan antara Pemenuhan kebutuhan psikologis dasar dan Engagement menunjukkan bahwa terdapat hubungan yang positif namun temasuk korelasi sangat lemah dan signifikan anatara kedua variabel tersebut. Menurut Ryan dan Deci, (2000) setiap orang pada dasarnya akan mencari pengalaman yang akan yang dapat memenuhi kebutuhan competence, autonomy dan relatedness dari lingkungannya. Berdasarkan pengalaman yang diperolehnya dari lingkungan, individu akan menilai apakah kebutuhan psikologis yang mendasar dalam dirinya terpenuhi atau tidak (Connell \& Wellborn, 1991). berdasarkan pengalamanpengalaman ini, seseorang secara kumulatif akan membangun pandangan mengenai diri mereka sendiri (Connell \& Wellborn, 1991). Pandangan atau anggapan terhadap diri ini bukanlah persepsi mengenai diri yang cepat lenyap begitu saja, melainkan keyakinan yang 
bertahan lama yang membentuk realita nyata pada diri seseorang dan menuntun tidakan seseorang (Connell \& Wellborn, 1991; Pitzer \& Skinner, 2016; Ryan \& Deci, 2017).

Pada saat individu menghayati kebutuhan psikologis dasarnya terpenuhi maka akan individu tersebut akan memiliki perasaan bahwa mereka mampu mengatur dan melakukan suatu tindakan (sense competence), sebaliknya tidak memiliki sense competence akan mengancam perasaan bahwa individu tersebut mampu melakukan suatu tindakan (Connell \& Wellborn, 1991). Terpenuhi kebutuhan psikologis dasar ini menimbulkan perasaan bersedia dan memiliki kemauan sehubungan dengan melakukan suatu perilaku (sense autonomy) (Deci et al., 1989; Deci \& Ryan, 1994; Ryan \& Deci, 2017). Sense autonomy menggambarkan individu yang mengalami self endorsement dan ownership terhadap tindakannya, artinya adanya kebutuhan bahwa dirinyalah yang mengesahkan ataupun menentukan suatu tindakannya. Selain itu dengan terpenuhinya kebutuhan psikologis dasar seseorang akan memiliki perasaan bahwa orang lain menunjukkan kepedulian terhadap dirinya, serta pada dirinya memiliki kesempatan untuk memberikan kasih sayangnya terhadap orang lain (sense relatedness) (La Guardia, Ryan, Couchman, \& Deci, 2000).

Apabila seorang terpenuhi ketiga kebutuhan psikologis dasarnya maka akan lebih mendorong motivasi instrinsik dalam dirinya (Jang, Reeve \& Deci, 2010). Motivasi intrinisik ini merupakan sumber energi spontan dari manusia untuk melakukan eksplorasi dan mempertahankan ketekunan (persistence) dalam melakukan suatu aktivitas(Ryan \& Connell, 1989; Vollerand, 1997). Motivasi intrinsik dalam diri siswa akan memberikan energi untuk siswa dalam beraktivitas dan diwujudkan siswa dalam bentuk perilaku keterlibatan secara aktif dengan aktivitas di kelas. Dan memberikan energi untuk siswa dengan terlibat secara mental dengan aktivitas dikelas, misalnya dengan memusatkan perhatiannya pada aktivitas yang diberikan di kelas (Frederick et al 2004, Skinner \& Pitzer, 2012), dan terdorong untuk menguasai hal-hal yang dituntut dalam aktivitas di kelas secara lebih mendalam (Connell \& Wellborn, 1991) karena dianggap penting bagi dirinya.

Hasil penelitian ini mendukung pentingnya peran guru dalam bentuk teacher autonomy support dalam memenuhi kebutuhan psikologis dasar dan nantinya akan membentuk engagement siswa SMA di kota Bandung. Terutama pada siswa SMA yang berada dalam tahap usia perkembangan remaja. Bagi remaja, memiliki autonomy, menetapkan tujuan pribadi, membuat rencana masa depan adalah tugas perkembangan penting yang harus dicapai oleh seorang remaja. Menjadi self determinated atau mampu menjadi penggerak bagi dirinya sendiri dalam berbagai area kehidupan, yang dalam hal ini adalah pendidikan menjadi tugas perkembangan yang harus dicapai oleh remaja untuk menjadi manusia yang dewasa yang kelak dapat bertanggung jawab.

Beberapa keterbatasan dalam penelitian ini adalah, bahwa secara metodologi penelitian ini hanya dilakukan pada salah satu SMA saja dengan 213 siswa. Dengan jumlah responden yang terbatas ini, perlu dilakukan penelitian lanjutan dengan cakupan lokasi yang lebih luas sehingga diperoleh hasil penelitian yang dapat diaplikasikan pada populasi yang luas.

Selain teacher autonomy support, kajian literatur mengidentifikasi adanya peranan dari teacher structure dan involvement. Ketiga bentuk dukungan guru ini ini potensial memberikan dampak yang berbeda pada pemenuhan kebutuhan psikologis dasar yaitu need for autonomy, competence dan relatedness (Appleton, Christenson dan Furlong, 2008). Oleh karena itu terbuka peluang bagi dilakukannya penelitian yang menguji dampak ketiga dimensi dukungan guru ini terhadap pemenuhan kebutuhan psikologis dasar maupun pada engagement dan educational outcomes lainnya.

\section{Kesimpulan}

Secara keseluruhan dapat disimpulkan bahwa perilaku keterlibatan terhadap aktivitas belajar di kelas yang ditunjukkan oleh siswa, tergantung dari teacher autonomy support yang diterima siswa dan penghayatan siswa mengenai pemenuhan kebutuhan psikologis dasarnya. Implikasi dari temuan ini bahwa guru harus menyadari bahwa setiap siswa memiliki kebutuhan psikologis dasar yang dapat dipenuhi oleh perlakuan guru berupa autonomy support dan hal ini akan membentuk engagement siswa terhadapa aktivitas belajar di kelas. 


\section{Daftar Pustaka}

Appleton, J. J., Christenson, S. L., \& Furlong, M. J. (2008). Student engagement with school: Critical conceptual and methodological issues of the construct. Psychology in the Schools. 45(5):369 386. DOI: $10.1002 /$ pits. 20303

Baron, R. M., \& Kenny, D. A. (1986). The moderator-mediator variable distinction in social psychological research: Conceptual, strategic, and statistical considerations. Journal of Personality and Social Psychology, 51(6), 1173-1182.

Connell, James P, \& James G Wellborn. (1991). Competence, Autonomy, and Relatedness: A Motivational Analysis of Self-system Processes. In Self processes and development.The Minnesota symposia on child psychology, Vol. 23. Self processes and development(pp. 4377). Hillsdale, NJ, US: Lawrence Erlbaum Associates, Inc.

Fredricks, J. A., Blumenfeld, P. C., \& Paris, A. H. (2004). School Engagement: Potential of the Concept, State of the Evidence. Review of Educational Research, 74(1), 59-109. doi:10.3102/00346543074001059

Grolnick, W. M., \& Ryan, R. (1990). Selfperception, motivations, and adjustment in children with learning disabilities:a multiple group comparison study. Journal of Learning Disabilities. DOI :10.3102/00346543074001059

Jang, H., Reeve, J., \& Deci, E. L. (2010). Engaging Students in Learning Activities: It is Not Autonomy Support or Structure but Autonomy Support and Structure. Journal of Educational Psychology, 102(3):588-600. DOI: 10.1037/a0019682

La Guardia, J. G., Ryan, R. M., Couchman, C. E., \& Deci, E. L. (2000). Within-Person Variation in Security of Attachment. Journal of Personality and Social Psychology. 79(3), 367-384.

Reeve, J., \& Jang, H. (2006). What teachers say and do to support students' autonomy during a learning activity. Journal of Educational Psychology, 3, 367-384.

Ryan, A. M. (2012). Peer relationships and adjustment at school: An introduction. In Peer relationships and adjustment at school. Charlotte, NC, US: IAP Information Age Publishing.

Ryan, R., \& Deci, E. (2000). Self-determination theory and the facilitation of intrinsic motivation. American Psychologist All Pages. 55 (1), 68-78.

Ryan, R. M., \& Lynch, J. H. (1989). Emotional autonomy versus detachment: revisiting the vicissitudes of adolescence and young adulthood. Child Development, $60,340-356$.

Ryan R.M dan Decy E.L. (2000). Selfdetermination theory and the facilitatiton of intrinsic motivation, social development, and well-being. American Psychological Association.

Ryan, Richard M., \& Deci, E. L. (2000a). Intrinsic and Extrinsic Motivations: Classic Definitions and New Directions. Contemporary Educational Psychology.25, 54-67

Ryan, Richard M., \& Deci, E. L. (2000b). Self-determination theory and the facilitation of intrinsic motivation, social development, and well-being. American Psychologist. 55, 68-78

Ryan, Richard M., Deci, E. L., Grolnick, W. S., \& La Guardia, J. G. (2015). The Significance of Autonomy and Autonomy Support in Psychological Development and Psychopathology. In Developmental Psychopathology: Second Edition. doi. org/10.1002/9780470939383.ch20

Ryan, R., \& Powelson, C. (1991). Autonomy and Relatedness as Fundamental to Motivation and Education. The Journal of Experimental Education, 60(1), 4966. Retrieved from http://www.jstor.org/ stable/20152311

Ryan, Richard M, \& Deci, E. L. (2006). Chirkov, V. I., \& Ryan, R. M. (2001). Parent and teacher autonomy-support in Russian and U.S. adolescents: Common eff ects on well-being and academic motivation. Journal of Cross-Cultural Psychology.40.1-56. Lincoln: University of Nebraska Press.

Ryan, Richard M, \& Deci, E. L. (2017). Self-Determination Theory. An Introduction and Overview. SelfDetermination Theory: Basic Psychological Needs in Motivation, Development, and Well-being. American Psychologist. 55, 68-78

Ryan, Richard M, Deci,E. L., \& Grolnick, W. S. (1995). Autonomy, relatedness, and the self: Their relation to development and psychopathology. Developmental Psychopathology. Theory and methods (pp.618-655). New York : Wiley. LI 
Skinner, E.A., Pitzer, J.R., \& Brule, H.A. (2014). The Role of Emotion in Engagement, Coping, and the Development of Motivational Resilience. doi.org/10.4324/9780203148211.ch17

Skinner, E. A., \& Belmont, M. J. (1993). Motivation in the Classroom: Reciprocal Effects of Teacher Behavior and Student Engagement Across the School Year. Journal of Educational Psychology.85, 571-581.

Skinner, E. A., Kindermann, T. A., Connell, J. P., \& Wellborn, J. G. (2009a). Engagement and disaffection as organizational constructs in the dynamics of motivational development. Educational anad Psychological Measurement, 69, 493-525

Skinner, E. A., Kindermann, T. A., Connell, J. P., \& Wellborn, J. G. (2009b). Engagement and Disaffection as Organizational Constructs in the Dynamics of Motivational Development. In Handbook of motivation at school. (pp.223-246). New York : Routledge.

Skinner, E. A., \& Pitzer, J. R. (2012a). Developmental dynamics of student engagement, coping, and everyday resilience. In S.L.Christenson, A.L.Reschly, \& C. Wylie (Eds.),Handbook of Research on Student Engagement. (pp.21-44). New York: Spinger Science.

Skinner, E. A., \& Pitzer, J. R. (2012b). Handbook of Research on Student Engagement. 21-44. Newyork, NY : Springer Science.

Skinner, E. A., Pitzer, J. R., \& Steele, J. S. (2016). Can student engagement serve as a motivational resource for academic coping, persistence, and learning during late elementary and early middle school? Developmental Psychology, 52(12), 20992117.

Skinner, E. A., Wellborn, J. G., \& Connell, J. P. (1990). What It Takes to Do Well in School and Whether I've Got It: A Process Model of Perceived Control and Children's Engagement and Achievement in School. Journal of Educational Psychology. 82(1), 22-32.

Skinner, E. A., Zimmer-Gembeck, M. J., Connell, J. P., Eccles, J. S., \& Wellborn, J. G. (2006). Individual Differences and the Development of Perceived Control. Monographs of the Society for Research in Child Development. San Francisci, CA : Jossey-Bass.
Skinner, E. a, Kindermann, T. A., Connell, J. P., \& Wellborn, J. G. (2009). Engagement and disaffection as organizational constructs in the dynamics of motivational development. Handbook of Motivation in School (pp. 223-245). Mahwah, NJ: Erbaum.

Skinner, E., Furrer, C., Marchand, G., \& Kindermann, T. (2008). Engagement and Disaffection in the Classroom: Part of a Larger Motivational Dynamic? Journal of Educational Psychology, 100(4), 765781.

Skinner, E., Pitzer, J., \& Brule, H. (2014). The role of emotion in engagement, coping, and the development of motivational resilience. In International Handbook of Emotions in Education. doi. org/10.4324/9780203148211.ch17

Skinner, E., Pitzer, J., \& Steele, J. (2013). Coping as Part of Motivational Resilience in School: A Multidimensional Measure of Families, Allocations, and Profiles of Academic Coping. Educational and Psychological Measurement. 73 (5) : 803-835 